\title{
UNREPORTED PRACTICE CASES
}

\section{JUDGMENT-RECIPROCAL ENFORCEMENT-MERGER- STRIKING OUT*}

Defendants moved to strike out a Statement of Claim for debt on the grounds that the cause of action was res judicata. Default judgments had been obtained in Manitoba in respect of the same cause of action.

The Manitoba judgments had, in fact, been registered in Alberta under The Reciprocal Enforcement of Judgments Act, and were, for the purposes of that Act, Alberta judgments. In the instant action the plaintiff had sued the same defendants on the original cause of action. By the time the application was made, the Alberta registration had been set aside, and the main argument that the court had to consider was based on the fact that there was a Manitoba judgment for the same cause of action.

The Master held that the application to strike out failed. The doctrine of res judicata or merger does not apply to a foreign judgment. The court cited Dicey \& Morris, Conflict of Laws, 1002 (84th ed.); Graveson, Conflict of Laws, 637, 660 (6th ed.); Castel, Conflict of Laws, 1060 (2nd ed.); Trevelyan v. Myers (1895) 26 O.R. 430; I.A.C. v. Stevenson (1963) 43 W.W.R. 126; and Carl Zeiss Stiftung v. Rayner [1967] A.C. 853.

The Master also referred to $\mathrm{s}$. 11 of The Reciprocal Enforcement of Judgments Act, which preserves the plaintiff's right to bring an action on his original judgment or cause of action. There could, then, be a multiplicity of proceedings, indeed, a multiplicity of judgments. Had the Alberta registration not been set aside the Master "would have been constrained to strike out the Statement of Claim or stay it as abuse of process," since there would have been, by virtue of Section 3 of the Act an outstanding Alberta judgment.

(Trans-Continental Truck Terminals Ltd. v. Palmer et al., S.C.A., J.D.E., S.C. No. 73922, Dec. 22, 1972, L. D. Hyndman, Q.C., Master in Chambers.)

"Editor's Note: Appeal to Primrose J. dismissed February 8, 1973.

\section{LEAVE TO TAKE NEXT STEP-DISMISSAL FOR WANT OF PROSECUTION-PRINCIPLES INVOLVED-THIRD PARTY, BY ORDER}

The plaintiff applied for leave to take the next step, and the third party, by order, applied to dismiss for want of prosecution.

No steps .were taken between September 1966 and May 1970, at which time an application for leave to take the next step was initiated but not proceeded with. The delay was explained by illness of counsel for the defence and uncertainty about the plaintiff's condition. The 
third party by Order took the position the named defendant had failed to co-operate with them and, indeed, his whereabouts were unknown.

The Master stated that the principles involved in this kind of application were inordinate delay, inexcusable delay and prejudice to the defendant. He cited numerous authorities, including Tiesmaki v. Wilson (1972) 23 D.L.R. (3d) 179 and Edward v. Kozans [1972] 3 W.W.R. 556. The Master said that the delay was not altogether satisfactorily explained, but he refused to characterize it as inordinate (or excessive) or inexcusable. As for prejudice, the defendant not being represented, did not show prejudice. His insurer, a third party by order, only appeared as a party, as distinct from the defendant, while the particular application was pending.

(Rawlings v. Campbell, S.C.A., J.D.E., S.C. No. 45957, Sept. 28, 1972, L. D. Hyndman, Q.C., Master in Chambers.)

\section{SERVICE EX JURIS-EVIDENCE IN SUPPORT OF ORDER- THIRD PARTY NOTICE-EXTENSION OF TIME UNDER RULE $66 . *$}

One of three defendants obtained an Order, with the consent of the plaintiff, extending the time for serving a third party Notice. The Order was obtained ex parte, and without an affidavit in support, on March 16, 1972; the defence having been filed in September of 1970 and amended in February 1972. Discoveries had been held and the action entered for trial at the time the impugned order was obtained.

The Master set aside the Order on the application of the third party. He held Rule 31 to be mandatory and to require sworn evidence.

He then went on to hold that the order extending time for filing and serving the third party notice should be set aside on the grounds of inordinate delay, absence of a credible excuse for the delay, and prejudice to the proposed third party.

He held that the application was not one to summarily strike out a pleading, but more akin to an order to dismiss for want of prosecution under Rule 244.

The excuse presented by counsel for the defendant was that the facts entitling it to third party emerged only on the discovery. The Master considered the discovery and affidavit of documents and pointed out that the defendant must have knowledge of the facts which enabled it to claim over when it was served with the Statement of Claim. The defendant claimed in the impugned third party notice that the third party was liable under a contract dated in 1968.

The third party objected, inter alia, that it had been unable to participate in the discovery already held; that the imminence of the trial might preclude it from having the opportunity in a discovery; and that it was now unable to examine the engine, the performance of which was the subject of the action. The defendant pointed out it could still bring a separate action. The Master said that a separate action might be brought and multiplicity of actions was a consideration, but he was not satisfied that there would be a redundance of costs in a second action. He concluded the third party was likely to be prejudiced by the delay in bringing the third party into the action. 
The Master also referred to Rule 78 and stated that the plaintiff might be prejudiced also. True he had consented to the original order, but his consent was not necessary, and the issues now emerging had not then appeared. The words of Rule 78 "questions between the defendant and the third party in which he is not concerned" means "questions ... in respect of which he, the plaintiff, does not take issue". Moreover, it was difficult to see how any order could be made under Rule 78 which did protect the plaintiff.

The application was granted with costs taxed in favour of the applicant on a solicitor and client basis.

(Kreway v. Renfrew Chrysler Plymouth Ltd. et al., S.C.A., J.D.C., S.C. No. 99343, August 16, 1972, A. D. Bessemer, Q.C., Master in Chambers.)

-Case appealed-see following Unreported Case Note.

\section{KREWAY v. RENFREW CHRYSLER}

This decision was appealed and affirmed except as to costs. The Chambers Judge agreed that the failure to produce the affidavit required by Rule 31 was fatal, the Rule calling for strict compliance, citing Sunnyside Greenhouse Ltd. v. Golden West Seeds Ltd. (1970) 75 W.W.R. 624. The Chambers Judge, Cullen J., held that no lawful or reasonable excuse for the inordinate delay had been given.

On the question of costs the Chambers Judge held that the award of costs on a solicitor and client basis was an incorrect exercise of the Master's discretion and authority, and quoted Wright et al. v. Long Branch [1959] S.C.R. 418 at 427, and Patton v. Toronto General Trusts Corp. [1930] A.C. 629 at 639.

(Kreway v. Renfrew Chrysler, S.C.A., J.D.C., S.C. No. 99343, Oct. 16, 1972, Cullen J.)

Unreported Practice Cases edited by Professor W. R. Stevenson. Faculty of Law, The University of Alberta,
Edmonton. 